\title{
ChemComm
}

Cite this: Chem. Commun., 2013, 49, 4385

Received 11th October 2012, Accepted 12th December 2012

DOI: $10.1039 / \mathrm{c} 2 \mathrm{cc3} 3416 a$

\section{The role of copper in catalytic performance of a Fe-Cu-Al-O catalyst for water gas shift reaction $† \neq$}

\author{
Yingchun Ye, Lei Wang,§ Shiran Zhang, Yuan Zhu, Junjun Shan and \\ Franklin (Feng) Tao*
}

www.rsc.org/chemcomm

\begin{abstract}
A Fe-Cu-Al-O water gas shift catalyst with a Fe : $\mathrm{Cu}$ atomic ratio of $4: 1$ upon pretreatment at $350{ }^{\circ} \mathrm{C}$ in $\mathrm{H}_{2}$ exhibits a conversion higher than a physical mixture of $\mathrm{Fe}-\mathrm{Al}-\mathrm{O}$ and $\mathrm{Cu}-\mathrm{Al}-\mathrm{O}$ by $\sim \mathbf{4 0 \%}$ over a temperature range of $300{ }^{\circ} \mathrm{C}-450{ }^{\circ} \mathrm{C}$. In situ ambient pressure X-ray photoelectron spectroscopy studies suggest that the surface region of $\mathrm{Fe}-\mathrm{Cu}-\mathrm{Al}-\mathrm{O}$ was restructured into a double-layer structure consisting of a surface layer of $\mathrm{Fe}_{3} \mathrm{O}_{4}$ and a metallic $\mathrm{Cu}$ layer below it upon pretreatment at $350{ }^{\circ} \mathrm{C}$. The strong metal $\left(\mathrm{Cu}\right.$-oxide $\left(\mathrm{Fe}_{3} \mathrm{O}_{4}\right)$ interface effect of this double layer structure enhances the catalytic activity of $\mathrm{Fe}_{3} \mathrm{O}_{4}$ in WGS.
\end{abstract}

The water-gas shift (WGS) reaction is critical in production of $\mathrm{H}_{2}$ in chemical industries and removal of carbon monoxide in $\mathrm{H}_{2}$ sources. Until recently there has been a lack of a satisfactory and wholly accepted picture of the mechanism of WGS at the molecular level. For WGS reactions used in chemical industries, $\mathrm{Cu}$ catalysts and $\mathrm{Fe}-\mathrm{Cr}-\mathrm{O}$ catalysts are typically used for low temperature and high temperature WGS, respectively. Many efforts have been made to improve the catalytic performance of Fe-based catalysts. ${ }^{1}$ For example, potential promotional roles of $\mathrm{Co}, \mathrm{Bu}, \mathrm{Ag}, \mathrm{Ba}, \mathrm{Ce}$ for $\mathrm{Fe}-\mathrm{Cr}-\mathrm{O}$ catalysts were examined. ${ }^{2-10}$

$\mathrm{Fe}-\mathrm{Cu}-\mathrm{Al}-\mathrm{O}$ catalysts ${ }^{2,3,9}$ reported recently exhibit a comparable catalytic performance to $\mathrm{Fe}-\mathrm{Cr}-\mathrm{O}$ and other Fe-based catalysts. ${ }^{8} \mathrm{Cu}$ is considered as a promoter for the high temperature WGS catalysts, $\mathrm{Fe}-\mathrm{Cu}-\mathrm{Al}-\mathrm{O}$. The mechanism of promotion by copper in $\mathrm{Fe}-\mathrm{Cu}-$ $\mathrm{Al}-\mathrm{O}$ is still unclear. One hypothesis is that $\mathrm{CuO}$ is reduced to metallic $\mathrm{Cu}$ which provides active sites for WGS even at high temperature. Another argument is that the integration of $\mathrm{CuO}$ into $\mathrm{Fe}_{3} \mathrm{O}_{4}$ could aid charge transfer since an effective charge transfer between $\mathrm{Fe}^{2+}$ and $\mathrm{Fe}^{3+}$ coordinating with octahedral oxygen atoms in $\mathrm{Fe}_{3} \mathrm{O}_{4}$ was proposed as the mechanism taking place on $\mathrm{Fe}_{3} \mathrm{O}_{4}{ }^{1,11}$ for high temperature WGS. Elucidation of the promotional effect of $\mathrm{Cu}$ in Fe-based WGS catalysts including $\mathrm{Fe}-\mathrm{Cu}-\mathrm{Al}-\mathrm{O}$ need to identify oxidation states of copper and iron and measure their surface compositions. Active phase can be oxidized readily once they are exposed to

Department of Chemistry and Biochemistry, University of Notre Dame, Notre Dame, IN 46556, USA. E-mail: ftao@nd.edu

† This article is part of the ChemComm 'Emerging Investigators 2013' themed issue. † Electronic supplementary information (ESI) available. See DOI: 10.1039/c2cc37416a $\S$ Current address: Institute of Process Engineering, Chinese Academy of Sciences, Beijing 100190, China. an ambient environment. Thus, it is necessary to carry out in situ studies which track the oxidation state of catalytic sites and measure the composition of the catalyst with high surface sensitivity during catalysis. Due to the technical challenge in such a surface analysis during catalysis, exploration of the promotional effect of $\mathrm{Cu}$ for WGS in Fe-based catalysts has been behind the advance ${ }^{2,3,9}$ in catalyst synthesis and experimental evaluation of their catalytic performances.

Here we synthesized an $\mathrm{Fe}-\mathrm{Cu}-\mathrm{Al}-\mathrm{O}$ catalyst with an atomic ratio of $\mathrm{Fe}: \mathrm{Cu}$ of $4: 1$. In situ studies using in-house ambient pressure XPS (AP-XPS) ${ }^{12}$ in our group and measurement of catalytic performances were carried out under similar conditions. Surface composition and oxidation state of $\mathrm{Cu}$ and $\mathrm{Fe}$ were tracked and studied under reaction conditions. A correlation between surface chemistry and catalytic performance was built. This correlation suggests a strong metal $(\mathrm{Cu})$ and oxide $\left(\mathrm{Fe}_{3} \mathrm{O}_{4}\right)$ interaction which is responsible for the promotional effect of $\mathrm{Cu}$ on $\mathrm{Fe}_{3} \mathrm{O}_{4}$ in the $\mathrm{Fe}-\mathrm{Cu}-\mathrm{Al}-\mathrm{O}$ catalysts for WGS.

$\mathrm{Fe}-\mathrm{Cu}-\mathrm{Al}-\mathrm{O}$ was synthesized using a method reported by Ozkan et al. ${ }^{9} \mathrm{X}$-ray diffraction patterns of the as-synthesized $\mathrm{Fe}-\mathrm{Cu}-\mathrm{Al}-\mathrm{O}$ catalyst were readily assigned to hematite phase $\left(\gamma-\mathrm{Fe}_{2} \mathrm{O}_{3}\right.$, ICDD\#040755). Although magnetite $\left(\mathrm{Fe}_{3} \mathrm{O}_{4}, \mathrm{ICDD} \# 11-0614\right)$ has very similar diffraction patterns in the range of $20^{\circ}-70^{\circ}$, we do not think this is a magnetite phase since the last step of the preparation of these catalysts is calcination in air. In fact, only hematite phase was identified in the as-synthesized catalyst. Notably, there is neither metallic $\mathrm{Cu}$ nor oxide phase such as $\mathrm{Cu}_{2} \mathrm{O}$ or $\mathrm{CuO}$. XRD patterns suggested that copper does not exist as a separate phase; alternatively, $\mathrm{Cu}^{2+}$ is incorporated into the lattice of $\mathrm{Fe}_{2} \mathrm{O}_{3}$. The valence states of copper and iron in those catalysts were confirmed by our XPS studies and will be discussed in the following paragraphs.

Fig. 1 shows the catalytic performances of $\mathrm{Fe}-\mathrm{Cu}-\mathrm{Al}-\mathrm{O}$ (0.15 mmol iron and $0.0375 \mathrm{mmol}$ copper) upon different pretreatments (Fig. 1a and b) and a physical mixture of Fe-Al-O (0.15 mmol iron) and $\mathrm{Cu}-\mathrm{Al}-\mathrm{O}(0.0375 \mathrm{mmol}$ copper$)$ (Fig. 1c) upon a pretreatment at $350{ }^{\circ} \mathrm{C}$ in $\mathrm{H}_{2}$ for one hour. All these catalysts have the same amount of iron $(0.15 \mathrm{mmol})$. The difference in catalytic activity between $\mathrm{Fe}-\mathrm{Cu}-\mathrm{Al}-\mathrm{O}$ and a physical mixture of $\mathrm{Fe}-\mathrm{Al}-\mathrm{O}$ and $\mathrm{Cu}-\mathrm{Al}-\mathrm{O}$ is distinct. At $300{ }^{\circ} \mathrm{C}, \mathrm{Fe}-\mathrm{Cu}-\mathrm{Al}-\mathrm{O}(0.15 \mathrm{mmol})$ pretreated at $350{ }^{\circ} \mathrm{C}$ exhibits a higher conversion by $\sim 40 \%$ in contrast to a physical mixture of $\mathrm{Fe}-\mathrm{Al}-\mathrm{O} \quad(0.15 \mathrm{mmol})$ and $\mathrm{Cu}-\mathrm{Al}-\mathrm{O}$ 


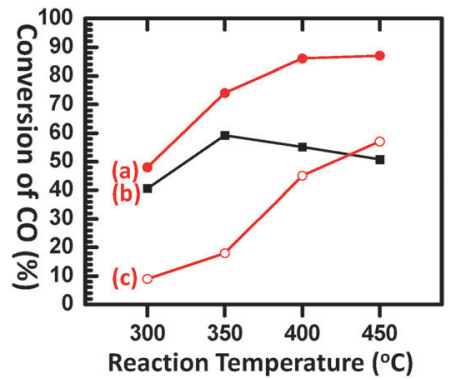

Fig. 1 Conversion of $\mathrm{CO}$ in WGS on Fe-Cu-Al-O upon pretreatment at $350{ }^{\circ} \mathrm{C}$ in $\mathrm{H}_{2}$ (a) and $400{ }^{\circ} \mathrm{C}$ in $\mathrm{H}_{2}$ (b) and on the physical mixture of Fe-Al-O and $\mathrm{Cu}-\mathrm{Al}-\mathrm{O}$ upon pretreatment at $350{ }^{\circ} \mathrm{C}$ in $\mathrm{H}_{2}$ (c).

(0.0375 mmol), which underwent the same pretreatment $\left(350{ }^{\circ} \mathrm{C}\right.$ in $\mathrm{H}_{2}$ ). In fact, over the catalytic temperature range of $300{ }^{\circ} \mathrm{C}$ $450{ }^{\circ} \mathrm{C}$, conversion of $\mathrm{Fe}-\mathrm{Cu}-\mathrm{Al}-\mathrm{O}$ is higher than that of the physical mixture by $\sim 40 \%$. This distinct difference shows the promotional effect of copper for WGS on $\mathrm{Fe}_{3} \mathrm{O}_{4}$.

To understand this promotional effect, surface chemistries of the $\mathrm{Fe}-\mathrm{Cu}-\mathrm{Al}-\mathrm{O}$ catalyst during catalysis were tracked with our in-house AP-XPS system ${ }^{12}$ under catalytic conditions. This system has a flow reactor integrated into a monochromated $\mathrm{Al} \mathrm{K} \alpha$ source and a differential pumping system. The catalyst is placed in the flow reactor. The volume of reactant/product gases in this reactor is about 10-15 $\mathrm{ml}$. The gas delivery system attached to the flow reactor allows a flow rate of reactant gases of $5-20 \mathrm{ml} \mathrm{min}^{-1}$, which is measured using mass flow controllers. This reactor has a window of $\mathrm{Si}_{3} \mathrm{~N}_{4}$ to transmit an $\mathrm{Al} \mathrm{K} \alpha$ and an aperture installed to engage a differential pumping system. The catalyst sample in a gas environment can be heated up to $600{ }^{\circ} \mathrm{C} .{ }^{12-14}$ The partial pressures of CO and $\mathrm{H}_{2} \mathrm{O}$ are 1 Torr for each gas in the reactor. The flow rate of each

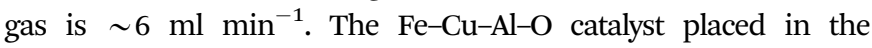
AP-XPS reactor was pretreated at $350{ }^{\circ} \mathrm{C}$ in 1 Torr $\mathrm{H}_{2}$ for one hour and then reactant gases were introduced for WGS reaction. During pretreatment and catalytic reaction, photoemission features of $\mathrm{Cu}$ 2p, Fe 2p, and Auger line Cu LMM were collected in the presence of reactant and product gases. The evolution of these photoemission features of $\mathrm{Cu} 2 \mathrm{p}, \mathrm{Fe} 2 \mathrm{p}$, and $\mathrm{Cu}$ LMM can reflect the changes of surface chemistry subject to the change of reaction conditions in terms of different reactants and reaction temperatures.

Fig. 2 presents the evolution of the $\mathrm{Cu}$ fraction in the total of $\mathrm{Cu}$ and Fe during pretreatment at $350{ }^{\circ} \mathrm{C}$ and the following catalytic reactions. A significant decrease of $\mathrm{Cu}$ fraction was identified upon pretreatment at $350{ }^{\circ} \mathrm{C}$ in $\mathrm{H}_{2}$. The measured fraction of the as-synthesized catalysts at room temperature in UHV is $23.5 \%$; it decreased to only $8.1 \%$. Fig. 3 a presents the spectra of $\mathrm{Cu} 2 \mathrm{p}$ during

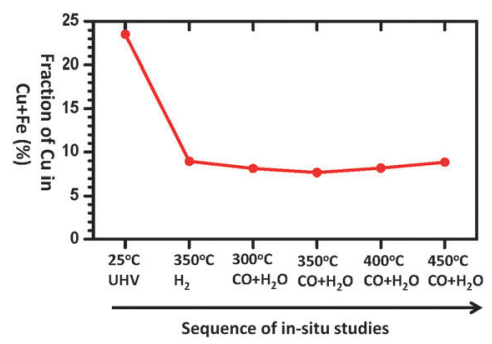

Fig. 2 Atomic fraction of $\mathrm{Cu}$ in the total of $\mathrm{Cu}$ and Fe measured with AP-XPS under reaction conditions (pretreatment and catalysis).
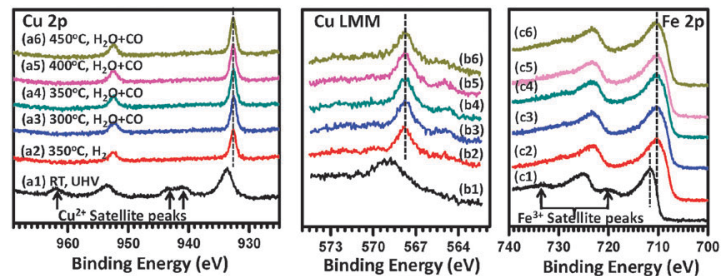

Fig. 3 AP-XPS studies of Cu 2p, Cu LMM and Fe 2p of the Fe-Cu-Al-O catalyst under reaction conditions upon pretreatment at $350{ }^{\circ} \mathrm{C}$ in $\mathrm{H}_{2}$.

pretreatment and catalysis. $\mathrm{Cu}^{2+}$ was clearly identified since the satellite peaks of $\mathrm{Cu} 2 \mathrm{p}_{3 / 2}$ at $941.0 \mathrm{eV}$ and $943.4 \mathrm{eV}$ and $\mathrm{Cu} 2 \mathrm{p}_{1 / 2}$ at $961.8 \mathrm{eV}^{15,16}$ were clearly identified in this study. The main peaks of $\mathrm{Cu} 2 \mathrm{p}$ at 933.7 and $953.6 \mathrm{eV}$ were clearly identified. The absence of photoemission peak at $932.7 \mathrm{eV}$ of $\mathrm{Cu}^{+} / \mathrm{Cu}^{15,16}$ shows a complete $\mathrm{Cu}^{2+}$ valence state of the as-synthesized catalyst. Photoemission features of $\mathrm{Fe} 2 \mathrm{p}$ at $711 \mathrm{eV}$ and $724.1 \mathrm{eV}$ and their satellite peaks (Fig. 3c1) show that the surface phase at room temperature is $\mathrm{Fe}_{2} \mathrm{O}_{3}$ instead of $\mathrm{Fe}_{3} \mathrm{O}_{4}$. Upon pretreatment at $350{ }^{\circ} \mathrm{C}$ in $\mathrm{H}_{2}, \mathrm{Cu} 2 \mathrm{p}$ satellite peaks disappeared and the peak position of $\mathrm{Cu} 2 \mathrm{p}_{3 / 2}$ down-shifted to 932.7 eV. Clearly, $\mathrm{Cu}^{2+}$ was reduced. Further analysis using the Auger parameter $^{15,16}$ showed that the reduced copper is in fact metallic copper instead of $\mathrm{Cu}^{+}$(Fig. 3b). The Auger parameter for copper in the catalyst upon pretreatment is $1851.2 \mathrm{eV}$, which is the same as the value of metallic $\mathrm{Cu}$ reported in other studies. ${ }^{15,16}$ Photoemission features of Fe 2p (Fig. 3c) suggest that $\mathrm{Fe}_{2} \mathrm{O}_{3}$ was reduced to $\mathrm{Fe}_{3} \mathrm{O}_{4}$ upon pretreatment at $350{ }^{\circ} \mathrm{C}$ in $\mathrm{H}_{2}$. Notably, there is no photoemission feature at the peak position of metallic $\mathrm{Fe}^{17}$ at $707.0 \mathrm{eV}$ and $720.1 \mathrm{eV}$. Thus, there is no metallic Fe formed during the reduction. The in situ studies using AP-XPS showed that $\mathrm{Cu}^{2+}$ in the $\mathrm{Fe}-\mathrm{Cu}-\mathrm{Al}-\mathrm{O}$ (Fig. 4a) is reduced to its metallic form, and iron exists in the form of $\mathrm{Fe}_{3} \mathrm{O}_{4}$ upon pretreatment at $350{ }^{\circ} \mathrm{C}$ in $\mathrm{H}_{2}$ for one hour.

The decrease of atomic fraction upon pretreatment (from $\sim 24 \%$ to $\sim 8 \%$ ) does not allow us to suggest a segregation of metallic $\mathrm{Cu}$ to the surface since XPS is a surface-sensitive technique. In fact, this in situ surface observation shows that $\mathrm{Cu}$ is remained at a region near the surface (or subsurface) as schematically shown in Fig. 4b. The photoemission features of $\mathrm{Cu} 2 \mathrm{p}$ and $\mathrm{Fe} 2 \mathrm{p}$ of the $\mathrm{Fe}-\mathrm{Cu}-$ $\mathrm{Al}-\mathrm{O}$ catalyst observed during WGS reactions show the preservation of chemical states of $\mathrm{Cu}$ and $\mathrm{Fe}_{3} \mathrm{O}_{4}$ during these reaction (Fig. 3).

It is well acknowledged that the active phase of $\mathrm{Fe}_{2} \mathrm{O}_{3}$ for WGS is $\mathrm{Fe}_{3} \mathrm{O}_{4} \cdot{ }^{1}$ Our in situ studies of a physical mixture of $\mathrm{Fe}-\mathrm{Al}-\mathrm{O}$ and $\mathrm{Cu}-\mathrm{Al}-\mathrm{O}$ are consistent with previous studies. During catalysis, copper and iron of the physical mixture of $\mathrm{Fe}-\mathrm{Al}-\mathrm{O}$ and $\mathrm{Cu}-\mathrm{Al}-\mathrm{O}$ exist in chemical states of $\mathrm{Cu}^{0}$ and $\mathrm{Fe}_{3} \mathrm{O}_{4}$, respectively. However, catalytic performance of the physical mixture in terms of conversion are much lower than that of the $\mathrm{Fe}-\mathrm{Cu}-\mathrm{Al}-\mathrm{O}$ catalyst. It suggested that the subsurface of metallic $\mathrm{Cu}$ in $\mathrm{Fe}-\mathrm{Cu}-\mathrm{Al}-\mathrm{O}$

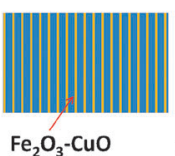

(a)

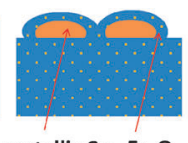

(b)

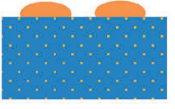

(c)

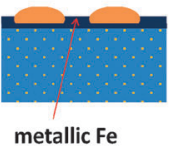

(d)
Fig. 4 Schematics showing surface structures under different conditions. (a) As-synthesized. (b) $\mathrm{Fe}_{3} \mathrm{O}_{4}-\mathrm{Cu}$ double layers during catalysis pretreatment at $350{ }^{\circ} \mathrm{C}$ in $\mathrm{H}_{2}$. (c) Potential $\mathrm{Cu}-\mathrm{Fe}_{3} \mathrm{O}_{4}$ structure. (d) Surface layer consisting of $\mathrm{Cu}$ and Fe nanoclusters during pretreatment at $400{ }^{\circ} \mathrm{C}$ in $\mathrm{H}_{2}$. 

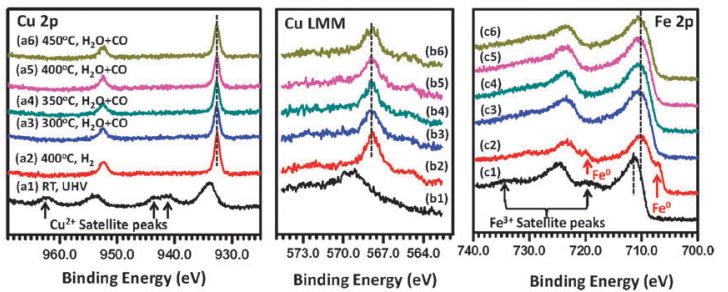

Fig. 5 AP-XPS studies of Cu 2p, Cu LMM and Fe $2 p$ of the Fe-Cu-Al-O catalyst under reaction conditions upon pretreatment at $400{ }^{\circ} \mathrm{C}$ in 1 Torr $\mathrm{H}_{2}$ for $1 \mathrm{~h}$.

formed during pretreatment at $350{ }^{\circ} \mathrm{C}$ and when located below the $\mathrm{Fe}_{3} \mathrm{O}_{4}$ layer plays a critical role in the promotion. As the atomic fraction of metallic $\mathrm{Cu}$ is significantly decreased (Fig. 2), a segregation of $\mathrm{Cu}$ to the surface and formation of $\mathrm{Cu}$ clusters on the surface of $\mathrm{Fe}_{3} \mathrm{O}_{4}$ (Fig. 4c) was not supported. As AP-XPS showed that $\mathrm{Fe}_{2} \mathrm{O}_{3}$ was reduced to $\mathrm{Fe}_{3} \mathrm{O}_{4}$ and $\mathrm{Cu}^{2+}$ to $\mathrm{Cu}$ during the pretreatment, we suggest that $\mathrm{Fe}_{3} \mathrm{O}_{4}$ is located above the subsurface $\mathrm{Cu}$ layer, as shown in Fig. $4 \mathrm{~b}$. The catalyst upon pretreatment can be considered as a reverse catalyst since oxide layers are supported by metal layers. Based on surface sensitivity of XPS, the thickness of the $\mathrm{Fe}_{3} \mathrm{O}_{4}$ layer could be a couple of $\mathrm{nm}$.

On the other hand, the as-synthesized $\mathrm{Fe}-\mathrm{Cu}-\mathrm{Al}-\mathrm{O}$ catalyst was pretreated at $400{ }^{\circ} \mathrm{C}$ in 1 Torr $\mathrm{H}_{2}$ for one hour. WGS reaction was performed after pretreatment at $400{ }^{\circ} \mathrm{C}$. Fig. $1 \mathrm{~b}$ presents the conversion of $\mathrm{Fe}-\mathrm{Cu}-\mathrm{Al}-\mathrm{O}$ at $300{ }^{\circ} \mathrm{C}-450{ }^{\circ} \mathrm{C}$ upon this pretreatment. AP-XPS studies of $\mathrm{Fe}-\mathrm{Cu}-\mathrm{Al}-\mathrm{O}$ upon pretreatment at $400{ }^{\circ} \mathrm{C}$ in $\mathrm{H}_{2}$ show that the atomic fraction of $\mathrm{Cu}$ is $16.3 \%$ instead of the $8.5 \%$ of the catalyst pretreated at $350{ }^{\circ} \mathrm{C}$. Surprisingly, it exhibits a quite different catalytic performance in contrast to that pretreated at $350{ }^{\circ} \mathrm{C}$. The conversion at $300{ }^{\circ} \mathrm{C}$ is $39.2 \%$ (Fig. 1b) which is $6 \%$ lower than that pretreated at $350{ }^{\circ} \mathrm{C}$ (Fig. 1a). The difference is larger at higher temperature. To understand this difference, in situ AP-XPS studies were performed upon pretreatment at $400{ }^{\circ} \mathrm{C}$. Fig. 5 presents the photoemission features of $\mathrm{Cu} 2 \mathrm{p}$ and $\mathrm{Fe} 2 \mathrm{p}$ of the $\mathrm{Fe}-\mathrm{Cu}-\mathrm{Al}-\mathrm{O}$ catalyst upon pretreatment at $400{ }^{\circ} \mathrm{C}$ in $\mathrm{H}_{2}$. Similar to the catalyst pretreated at $350{ }^{\circ} \mathrm{C}, \mathrm{Cu}^{2+}$ was reduced to metallic Cu. However, it is noted that $\mathrm{Fe}_{3} \mathrm{O}_{4}$ was partially reduced to metallic $\mathrm{Fe}$ upon pretreatment at $400{ }^{\circ} \mathrm{C}$ in $\mathrm{H}_{2}$, which is evidenced by the observation of the shoulders at $707.0 \mathrm{eV}$ and $720.1 \mathrm{eV}$ (Fig. 5c2). These peaks were not observed for the catalyst pretreated at $350{ }^{\circ} \mathrm{C}$ in $\mathrm{H}_{2}$ (Fig. 3c). The ratio of metallic Fe is about $12 \%$ of the total iron element or $10 \%$ of the total of iron and copper element. Thus, Fe is almost two thirds of the fraction of $\mathrm{Cu}$ in the surface region. Fig. $4 \mathrm{~d}$ schematically shows the structural model of the surface consisting of metallic $\mathrm{Cu}$ and $\mathrm{Fe}$ upon pretreatment at $400{ }^{\circ} \mathrm{C} . \mathrm{Fe}_{3} \mathrm{O}_{4}$ layers are buried below layers of $\mathrm{Cu}$ and $\mathrm{Fe}$. The photoemission features of $\mathrm{Fe} 2 \mathrm{p}$ and $\mathrm{Cu} 2 \mathrm{p}$ during catalysis upon pretreatment at $400{ }^{\circ} \mathrm{C}$ are presented in Fig. 5 . Notably, the peak of metallic Fe disappeared upon exposure to $\mathrm{H}_{2} \mathrm{O}$ and $\mathrm{CO}$ (c3-c6 in Fig. 5), though metallic $\mathrm{Cu}$ still remained. Based on the binding energy of the Fe 2p photoelectron, we expect that metallic iron formed during the pretreatment in $\mathrm{H}_{2}$ at $400{ }^{\circ} \mathrm{C}$ can be changed to an oxidizing state of iron such as $\mathrm{FeOOH}^{18}$ We excluded the possibility of oxidizing metal $\mathrm{Fe}$ to $\mathrm{Fe}_{3} \mathrm{O}_{4}$ since its catalytic performance is quite different from that pretreated at $350{ }^{\circ} \mathrm{C}$ (Fig. $1 \mathrm{~b}$ versus Fig. 1a). As $\mathrm{Cu}$ remains in its metallic state over the whole temperature range of $300{ }^{\circ} \mathrm{C}-450{ }^{\circ} \mathrm{C}$ (Fig. $5 \mathrm{~b}$ ), the metallic $\mathrm{Cu}$ is suggested to be the active phase on the $\mathrm{Fe}-\mathrm{Cu}-\mathrm{Al}-\mathrm{O}$

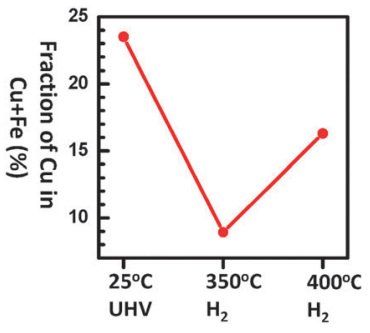

Fig. 6 Evolution of the $\mathrm{Cu}$ fraction in the total of $\mathrm{Cu}$ and Fe upon pretreatment at $350{ }^{\circ} \mathrm{C}$ and a followed one at $400{ }^{\circ} \mathrm{C}$ in 1 Torr $\mathrm{H}_{2}$ for $1 \mathrm{~h}$.

catalyst upon pretreatment at $400{ }^{\circ} \mathrm{C}$. Due to the lack of a $\mathrm{Fe}_{3} \mathrm{O}_{4}$ layer right next to the metallic $\mathrm{Cu}$ layer, there is no strong oxide-metal interaction in the $\mathrm{Fe}-\mathrm{Cu}-\mathrm{Al}-\mathrm{O}$ pretreated at $400{ }^{\circ} \mathrm{C}$. Conversion of $\mathrm{CO}$ is further decreased at $400{ }^{\circ} \mathrm{C}$ and $450{ }^{\circ} \mathrm{C}$. It probably results from aggregation of $\mathrm{Cu}$ clusters at a higher temperature.

In order to confirm the difference between restructured surfaces, $\mathrm{Fe}-\mathrm{Cu}-\mathrm{Al}-\mathrm{O}$ underwent a pretreatment at $350{ }^{\circ} \mathrm{C}$ (case 1), a pretreatment at $400{ }^{\circ} \mathrm{C}$ (case 2), and a sequential pretreatment at $350{ }^{\circ} \mathrm{C}$ and a followed pretreatment at $400{ }^{\circ} \mathrm{C}$ (case 3) for the same catalyst, simultaneous in situ studies of the catalyst surface using AP-XPS were performed. Fig. 6 presents the atomic fraction of case 3. Obviously, the atomic fractions of copper in the sequential pretreatments (case 3) in Fig. 6 are identical to those upon pretreatment performed at $350{ }^{\circ} \mathrm{C}$ (case 1) or $400{ }^{\circ} \mathrm{C}$ (case 2) independently. It confirmed that pretreatment at different temperature regimes forms different surface structures, which significantly influences the following catalytic performance.

In situ AP-XPS studies of $\mathrm{Fe}-\mathrm{Cu}-\mathrm{Al}-\mathrm{O}$ suggested that upon pretreatment at $350{ }^{\circ} \mathrm{C}$ in $\mathrm{H}_{2}$ copper is reduced to metallic $\mathrm{Cu}$ at the subsurface below a layer of $\mathrm{Fe}_{3} \mathrm{O}_{4}$ which is preserved during WGS reaction. This strong $\mathrm{Cu}-\mathrm{Fe}_{3} \mathrm{O}_{4}$ interface interaction significantly promotes the WGS on $\mathrm{Fe}_{3} \mathrm{O}_{4}$.

\section{Notes and references}

1 C. Rhodes, G. J. Hutchings and A. M. Ward, Catal. Today, 1995, 23, 43-58. 2 L. Zhang, X. Wang, J.-M. M. Millet, P. H. Matter and U. S. Ozkan, Appl. Catal., A, 2008, 351, 1-8.

3 L. Zhang, J.-M. M. Millet and U. S. Ozkan, Appl. Catal., A, 2009, 357, 66-72. 4 Q. S. Liu, W. P. Ma, R. X. He and Z. J. Mu, Catal. Today, 2005, 106, 52-56.

5 C. Rhodes, B. P. Williams, F. King and G. J. Hutchings, Catal. Commun., 2002, 3, 381-384.

6 Y. Lei, N. W. Cant and D. L. Trimm, J. Catal., 2006, 239, 227-236.

7 A. Andreev, V. Idakiev, D. Mihajlova and D. Shopov, Appl. Catal., 1986, 22, 385-387.

8 Q. S. Liu, Q. C. Zhang, W. P. Ma, R. X. He, L. J. Kou and Z. J. Mou, Prog. Chem., 2005, 17, 389-398.

9 S. Natesakhawat, X. Wang, L. Zhang and U. S. Ozkan, J. Mol. Catal. A: Chem., 2006, 260, 82-94.

10 C. Rhodes and G. J. Hutchings, Phys. Chem. Chem. Phys., 2003, 5, 2719-2723.

11 H. Topsoe and M. Boudart, J. Catal., 1973, 31, 346-359.

12 F. Tao, Chem. Commun., 2012, 48, 3812-3814.

13 Y. Zhu, S. Zhang, Y. Ye, X. Q. Zhang, L. Wang, W. Zhu, F. Cheng and F. Tao, ACS Catal., 2012, 2, 2403.

14 C. Wen, Y. Zhu, Y. Ye, S. Zhang, F. Cheng, Y. Liu, P. Wang and F. Tao, ACS Nano, 2012, 6, 9305.

15 M. C. Biesinger, L. W. M. Lau, A. R. Gerson and R. S. C. Smart, Appl. Surf. Sci., 2010, 257, 887-898.

16 M. C. Biesinger, B. P. Payne, A. P. Grosvenor, L. W. M. Lau, A. R. Gerson and R. S. C. Smart, Appl. Surf. Sci., 2011, 257, 2717-2730.

17 A. V. N. C. D. Wagner, A. Kraut-Vass, J. W. Allison, C. J. Powell and J. R. Rumble Jr., NIST Standard Reference Database 20, 2003.

18 J. F. Moulder, W. F. Stickle, P. E. Sobol and K. D. Bomben, Handbook of X-ray Photoelectron Spectroscopy, Perkin-Elmer Corporation, 1992. 